\title{
news pature
}

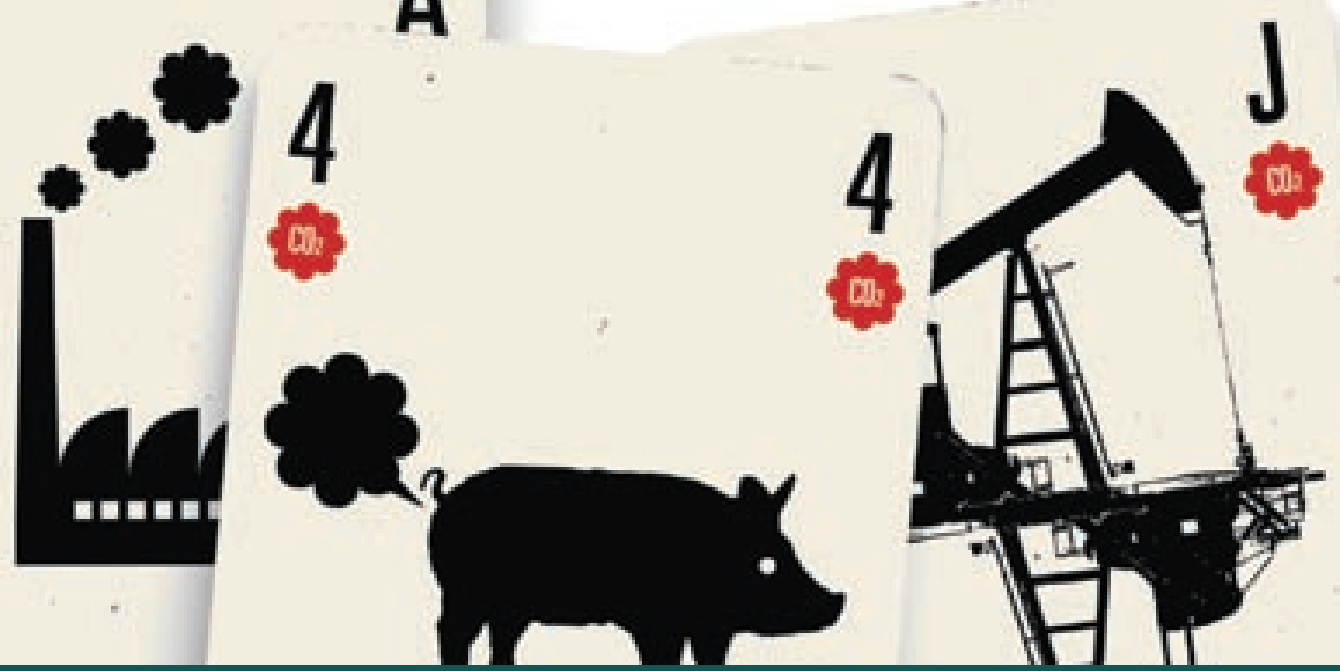

二酸化炭素などの温室効果ガスを企業が排出することを認める、排出権の売買がすでに始まっている。温室効果 ガスを吸収するように計画されたプロジェクトで利益を得る企業も現れている。こうした排出権取引市場が活況 を呈すれば、二酸化炭素の排出量を本当に減らすことができるのだろうか。Michael Hopkin が報告する。

2004 年夏、日本とカナダの電力会社 のグループが、豚のふんに並々ならめ 関心を寄せた。電力会社と、南米・チ リで最大の豚肉生産業者が行った数 百万ドル (数億円) 規模の画期的な取引。 その中心となるのが豚のふんだったの だ。この取引の結果、電力会社はより 多くの温室効果ガスを排出することが 可能になった。豚飼育場側は、ふんに 覆いをすることで、ふんから出るメ夕 ンガス（強力な温室効果ガス）をつか まえ、持続可能なエネルギーとして燃 やすことを約束。そうして電力会社は、 豚飼育場から地球を半周離れた発電所 で、より多くの二酸化炭素を排出でき る権利を買ったのだ。

この取引は 2004 年 8 月にサインさ れた。この種の取引の中でもスケール の大きなものだった。しかし、全くは じめてだったわけではない。温室効果 ガス排出権の売買は 1990 年代半ばか らすでに行われてきた。温室効果ガス
の削減を目指す国際協定である京都議 定書はその目標達成のため、二酸化炭 素排出権を企業が売買することを認め た。排出権売買の話が京都議定書が発 効していない段階で出てくるのは、奇 妙に聞こえるかもしれない。しかし口 シアが最近、京都議定書を批准したこ とで議定書の発効はまもなくという状 況のなか (Nature 431，1030; 2004 を参照)、排出権市場ではすでに活発な 取引が行われている。

排出権の取引市場は、その開始以 来、ゆっくりと成長してきた $(10 ヘ ゚$ ージのグラフを参照)。そして今、少 数の専門ブローカーの仲介のもと、爆 発的に増加しようとしている。2004 年末までに、二酸化炭素排出権取引の 総量は 2003 年の 2 倍になると予想 されている。しかし、排出権取引が本 当に広がるのは 2005 年だろう。欧州 連合 $(E U)$ は、2005 年 1 月に「排 出権取引制度」（ETS）をスタートさせ
る。この制度には、EU 加盟 25 力国の 約 12,700 の企業が参加する。ノルウ エーのオスロにあるコンサルタント会 社、ポイントカーボン社のアナリスト Henrik Hasselknippe によると、こ の欧州市場の取引額は、2007 年まで に年間 100 億ユーロ（約 1 兆 4000 億 円）に達する見込みだという。

\section{排出量を割り当て}

ETS での排出上限は「国内割り当て計 画」で決められる。これは EU 加盟各 国が提出する計画案で、現在、欧州委 員会で個別に承認されている。EU 加盟 国がその計画に承認を得ると、当該国 政府は割り当て量を電力会社、鉱山会 社、セメントメーカー、製紙会社など の産業設備に振り分け、国際的に取引 できる排出権を分配する。各国政府は、 これらの設備について、主に投入され る原料やエネルギーの量にもとづいて 排出量を監視し、登録取引情報ととも 
に数字を記録していく。二酸化炭素が 上限を超えて排出されると、企業は 1 トンあたり 40 ユーロ（約 5,600円） の誩金を払うことになる。この彊金は 2008 年以降、1トンあたり 100 ユー 口（約 14,000 円）に引き上げられる。 企業は、京都議定書の目標達成を目 指して作られた制度（ETSや、カナダ およびノルウェーでまもなく登場する システム）を利用するほか、排出権を独 自に売り出すことも行っている。これ には、企業が一定の社会的責任を株主 に示す目的もある。国内で公的に割り 当てられた二酸化炭素排出権を持たな い場合でも、企業は代わりに豚飼育場 との取引などの計画を売りに出す。米 国やオーストラリアなど、京都議定書 を批准していない国でさえも取引は行 われている。さらに、温室効果ガスの排 出を削減するためというよりも、運用 目的で市場を利用するとみられるデイ . トレーダー（個人投資家）たちも、ま もなくこの市場に参入してくるだろう。

ほとんどの人の排出権取引に関する 認識は、経済的に必要な、さらに環境 にもよいのかもしれないもの、といっ たところだ。企業にとって排出権を商 品に変えうることは、法的に実施する 必要があるからという以上に、企業活 動をクリーンにするための、財政面で の動機となる。米国で 1990 年代に自 発的に設立された小さな市場は、排出 量の削減が金銭に換算できるようにす ると排出量は減ることを証明したかの ように思われる。しかし、取引を全世 界的にみると、単に排出源が移動して いるだけで、排出の総量が減るかどう かは懐疑的だとする研究者や政治家も いる。彼らは、国内の排出量割り当て を決める交渉は寛大すぎたのではない か、と指摘する。また、排出権の価格 はあまりに安く、排出権を生み出すと されるプロジェクトが将来にわたって 確実に排出量を削減するかどうかの保 障はないという。

\section{米国での成功}

排出権市場のアイデアが京都議定書に 盛り込まれたのは、主に米国の圧力の ためだった。にもかかわらず、米国は 2001 年に議定書から離脱した。当時 は、企業が必要なときに余分に排出権 を買うことが許されないかぎり、多く の国は長期の排出量削減には同意でき ないだろうと考えられていた。排出権 取引制度があれば、排出コストの重荷 を負担すべきところに分散させること ができるだろう。このやり方は、別の 問題、特に二酸化硫黄（亜硫酸ガス）排 出量の削減に関してうまくいくと米国 で実証され、市場が環境ルールを順守 させる力を持つ証しと広くみなされた。

この米国の制度は「酸性雨プログラ 厶」といい、1990 年の米国の大気浄 化法の強化に応じて、石炭発電所から の二酸化硫黄の排出を減らす原動力と なった。このプログラムは、「キャップ. アンド・トレード」(上限と取引) とい う方針にもとづいて二酸化硫黄排出の 削減を進めた。排出量が多い、260を 超える発電所に排出量の上限が割り当 てられた。上限を超えざるをえない発 電所は、よりクリーンで排出量の少な い発電所から追加の排出権を買わなけ ればならなかった。米国のすべての石 炭発電所に排出権取引市場が開放され た 2000 年までに、二酸化硫黄の全国 的な排出量は、1980 年代後半の年間 およそ 1600 万トンから 1100 万トン にまで減少した 1

欧州の排出権取引制度（ETS）では、

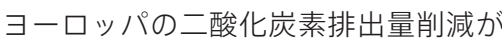
同様の手法で試されようとしている。 しかし、ETSには排出量を毎年約 1\% ずつ減らそうと努力している 25 力国 が参加する。一国の一産業分野だけで の取引だった米国の計画よりも、ずっ と難しい計画だ。米国のシンクタンク 「ピュー・センター・オン・グローバル. クライメト・チェンジ」(バージニア州 アーリントン) の経済学者で気候研究
者の Neil Strachan は「これだけの規 模での排出権取引を行った経験はだれ にもない」と話す。

この問題の行方を見守っている人た ちは、ETS が成功することを強く望ん でいる。排出量削減の手段となるだけ でなく、地球温暖化問題への取り組み における欧州の伝統的な指導力の証し ともなるからだ。もし、ETS がうまく いけば、2008 年には義務を果たし始 めなければならない残りの京都議定書 批准国に先例を示すことになる。

ETS における取引のほとんどは、メ ンバー間での排出権の直接の売買か、 「クリーン開発メカニズム」への投資か のどちらかになる。クリーン開発メカ ニズムは国連の制度で、発展途上国で の環境にやさしい産業の成長を促進す るためのものである。

クリーン開発メカニズムはすでに、 いくつかの革新的なアイデアを生み出 している。チリの豚もその一例だ。こ のほか、少数の計画が国連の厳格な検 証プロセスを通過した。この検証プロ セスでは、事業者が約束する二酸化炭 素排出権が確実に生み出されるものか をチェックする。検証プロセスを通過 したプランには、化学冷媒製造の副産 物として生じる温室効果ガス、HFC-23 を破壊するものや、ゴミ埋め立て地か ら発生するガスをエネルギーに变える ものなどが含まれている。しかし、こ の手の話の引き合いに出されることが 多い、ユーカリなどの成長の速い木を 植林して森を作り、二酸化炭素を吸収 するという計画で承認を得たものはま だない。計画をチェックする側は、こ の種の計画が確実なものであるとはま だ考えていないのだ。

二酸化炭素の排出量を制限するの ではなく、二酸化炭素を取り除いてし まおうというような現状のクリーン開 発メカニズムプロジェクトの効果の保 証は困難だという批判がある。今の ところ、そのようなプロジェクトによ 
成長産業 : 企業がより多くの二酸化炭素を 排出する権利を得る、排出権の取引は着実 に増加している。取引は 2004 年末までに は 2003 年の倍になると予想されている。

る二酸化炭素レベルの変化を予測し たり、変化が実際に起こったことを 確かめたりする正確な方法が存在しな い。たとえそういった方法があったと して、また別の問題は残ってしまうだ ろう。ダートマス大学（米国ニューハ ンプシャー州ハノーバー）の環境科学 者 Michael Dorsey は「ユーカリの 森を植えた後に、政権が変わって森を 伐採し、リゾート地を建設したらどう するのか。植林計画と引き換えに建設 した米国の発電所を壊すのか」と問い かける。排出権の問題だけでなく、二 酸化炭素排出量の超過を指摘する仕 組み、そして規則に従わないものを罰 する効果的な方法がなくては、排出量 を確実に減らすことはほぼ不可能だと Dorsey は主張する。

\section{課題は山積み}

クリーン開発メカニズムそのものが、 欧米の産業の発展を持続させる一方、 発展途上国には一時しのぎの解決策を もたらすだけだという批判もある。プ ロジェクトは発展途上国にいくらかの 産業と金をもたらすかもしれないが、 利益を得るのは一部の人間だ。現在、 排出量削減の 3 分の 2 以上が、わずか 5 力国によってもたらされている。イ ンド、ブラジル、チリ、ルーマニア、 インドネシアである2。アフリカ諸国の ほとんどでは、まだ取引が行われてい ない。そして、ロシアが登場すれば（そ れはまもなくと予想されている)、その 排出割当量で巨額の金を稼ぎ、市場の 相当部分を占めることになるはずだ。

ロシアはばく大な量の排出権を手に

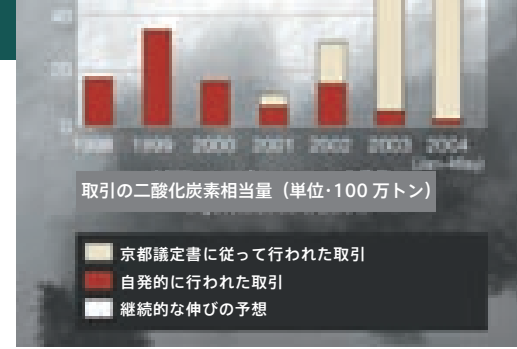

しそうだ。京都議定書の削減目標は、 基準年である 1990 年の排出量にもと づいているからである。当時、旧共産 主義体制の重工業は、まだ多量の二酸 化炭素を吐き出していた。1991 年の ソビエト連邦崩壊後、ロシアはこうし た工場を閉鎖した。その結果、割り当 てられた排出量に余剰が生じ、今度は それを転売できるようになっている。 排出権取引に批判的な者は、もし、 シアがすべての排出権を売り払ったら、 事実上、だれかがこうした旧式の発電 所をふたたびフル稼働させたのと同じ だけの二酸化炭素が排出されてしまう ことになると指摘する。それでも事態 は 14 年前よりはましだろうが、短期 的には排出量削減にとってマイナスと なるだろう。

さらなる懸念は、京都議定書で規制 が免除された産業から見込まれる排出 かもしれない。こうした産業分野は、 排出量の削減に寄与するとして設立さ れた排出権市場からも除外された。た とえば、車や航空機からの排出は国内 割り当てに含まれていない。「排出権取 引のシステムは、 $E \cup$ の総排出量の約 $50 \%$ しかバーしていない。輸送など のほかの分野はまだ成長を続けている」 と Hasselknippe は指摘する。

\section{気候取引所}

こうした批判にもかかわらず、排出権 取引市場の支持者と環境保護論者たち は、排出権取引は問題解決への唯一の 現実的な方法だと感じている。二酸化 硫黄の削減に、排出権取引がうまく機 能したことがその大きな理由だ。二酸
化硫黄の排出権市場も、当初数年間は 同じような批判に直面した。二酸化硫 黄排出権取引のプロジェクトに加わっ た「シカゴ気候取引所」(CCX) の最高 経営責任者、Richard Sandor は「二 酸化硫黄の取引を始めたとき、私たち は『スモッグ商人』や『ゴミ商人』と ののしられた。(環境保護団体の) グ リーンピースに監視されさえした。し かし、この取引のおかげで人命が守ら れた」と振り返る。「酸性雨プログラ ム」により米国経済は 12 億ドル（約 1,250 億円）のコストを負担したもの の、酸性雨の削減によって肺疾患の治 療費が 270 億ドル（約 2 兆 8,000 億円） 減少した、とSandor は言う。

Sandorは今、世界中の排出権を 扱う単一市場を目標にしつつ、ETS 参 加企業間の取引を仲介する「欧州気 候取引所」をスタートさせた。これも Sandor が監督する、シカゴ証券取引 所運営の自発的な二酸化炭素取引制度 の成功に続こうというものだ。この米 国市場には現在、フォード、IBM、デ ユポン、ロールスロイスなど、電力、 製造業、林業、農業の各分野から選ば れた約 75 社が参加している。これら の企業をあわせた排出量は、英国全体 よりも多い。参加企業は、毎年 $1 \%$ ず つ排出量を減らす契約にサインした。 しかし、Sandorによると 2003 年 12 月の取引開始以降、参加企業の総排出 量は $9 \%$ 減少したという。これは、排 出権市場が環境に有利に機能する証拠 だと、排出権市場の支持者は話す。

これらの米国企業の動機は、京都議 定書に伴う市場参入企業の動機とは大 


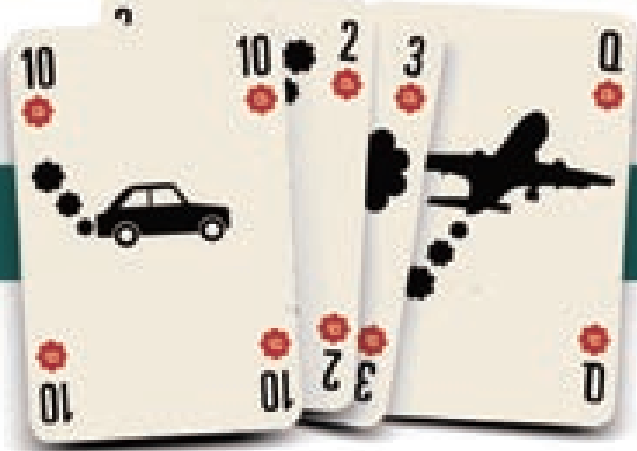

きく異なっている。排出量の多い企業 の一部は、現在タバコ産業に対して起 こされているような訴訟を避けるため に、何らかの行動を起こしたいのかも しれない、とSandorは言う。環境に やさしい産業に投資して、もうけたい 企業もあるだろう。これから出てくる かもしれない法律制定にあらかじめ対 応しておいたり、既存の環境ルールに 対応したい企業もあるだろう。たとえ ばオレゴン州では、発電所は二酸化炭 素排出量をもっとも効率的な複合サイ クル発電所の排出量より $17 \%$ 減らす義 務があり、さもなければ超過分につい て1トンあたり 0.85 ドルを支払わな ければならない?。

シカゴでの自発的な制度での規制 は、企業が目標とする削減レベルをコ ンサルタント会社が決定したものだっ たが、欧州の政府がトップダウン式に 言い渡した ETS での規制と驚くほど近 く、両者とも毎年 $1 \%$ の削減という目 標だった。これは関係者を勇気づけた。 企業の自己見積もりが政府による規制 と食い違わないならば、たとえ排出権 取引市場への各国の意気込みがまちま ちだとしても、世界規模での市場開設 の可能性は現実的だ、と多くの者が主 張する。

世界市場が設立されれば、理想的に は自動調節が起きてくるはずだ。政府 に強制された規制を真剣に守るほど排 出権の価格は高くなり、一部の企業は 排出権供給に向けてさらに懸命に努力 するだろう。

今のところ、ヨーロッパでの二酸化 炭素 1 トンの排出権の価格は、クリー ン開発メカニズムへの投資では 4 ユー 口（約 560 円）から 5 ユーロ、別の
市場参加企業との排出権取引では 8 ב 一ロ（約 1,120 円）から 9 ユーロであ る。市場の動向に注目している人たち は、これらの価格はとても低いと言う。 つまり、いくつかの国内割り当てプラ ンによって多くの欧州企業に比較的寛 大な上限が与えられた結果、市場参加 企業との取引での価格は 2004 年 2 月 時点よりもわずかに低い。しかし、チ リの豚飼育場の取引を仲介したロンド ンの co2e.com 社の Reena Qureshi は、「いったん市場が動き始めたら、ど んな価格もありえる。価格は、利率に も、価格が動くだろうと予想する一部 のアナリストの言葉にも、イラク戦争 のような政治的危機にも反応するだろ う」と話す。天候さえも市場を動かす かもしれない。2003 年夏のような焼 けつくような熱波が来たら、電力の使 用量は急上昇する。これは、電力会社 がより多くの排出権を買う必要が生じ る可能性を意味する。

\section{投機の対象に}

公式にスタートすれば、欧州の市場は 安易に金もうけを目論む個人デイ・卜 レーダーにも開かれるだろう。また、 デイ・トレーダーの関心を引くことは 期待されてもいる。世界中の二酸化炭 素排出の状況は、突然、パソコンの前 に座って株取引をしている人たちの強 い関心の的になるだろう。そうなれば、 この市場は少なくとも地球温暖化の意 識向上の一助にはなる。

一部の評論家は、排出権がどのよう な価格で取引されたとしても、二酸化 炭素排出にかかる本当のコストに比べ ると常に安すぎることになると言う。 コンサルタント会社「プライスウォー
ターハウスクーパーズ」のロンドンの アナリスト、Melissa Carringtonは「排 出権取引価格を社会的コストと一致さ せる仕組みはない」と話す。ETS 参加 企業の場合、罰金は 1 トンあたり 40 ユーロだが、この罰金が市場価格に上 限を設けることになるだろう。この価 格はあまりに低いとみる者が多い。英 国政府が行ったある研究では、気候変 動が社会におよぼす総コスト（洪水、 極端な天候、健康問題などによる）を、 二酸化炭素排出量 1 トンあたり約 100 ユーロと見積もっている3。

それでも排出権売買制度の支持者 は、排出権市場は企業を排出量削減へ と誘導するための経済的に実行可能な 方策だと指摘する。排出権取引が盛り 込まれなければ、京都議定書は採択さ れなかっただろう。実際には排出権取 引が導入された結果、企業は排出量の 削減がお金に等しいことを悟り、市場 は企業をよい方向に導く。これは、た とえば電力会社が排出量を管理したり、 豚飼育場がふんをリサイクルしたりす ることを促す。そして、それは間違い なくよいことだ。

Michael Hopkin は、ロンドンの news@nature.com 記者。

\footnotetext{
1. Ellerman, A. D., Joskow, P. L. \& Harrison, D. Emissions Trading in the US: Experience, Lessons and Considerations for Greenhouse Gases (Pew Center on Global Climate Change, Arlington,VA, 2003).

2. Lecocq, F. State and Trends of the Carbon Market 2004 (Carbon Finance at the World Bank,Washington DC, 2004)

3. Clarkson, R. \& Deyes, K. Estimating the Social Cost of Carbon Emissions Government Economic Service Working Paper 140 (HM Treasury, London, 2002).
} 